\title{
The Theme of Loneliness and Isolation in Sherwood Anderson's Fiction
}

\author{
Dr. Ali Mohammed Segar \\ Al-Ma'moon University College; Dept. of English \\ ali segar@yahoo.com
}

\section{ABSTRACT}

The aim of this research is to study the American writer Sherwood Anderson( 1876-1941) and his contribution in the American fiction in one of its most remarkable phases : that period of change and literary experimentalism that occurred after the First World War. In this period a new passion and consciousness comes into American writing .It is also thought of as a classic era of materialism, and business - ethics which the writers regularly condemned and expatriated themselves from it. The sense of loneliness and isolation is apparently depicted in Anderson's writings as a clear reflection of the general sense of American society at that time with the spread of commercial and industrial tendencies. The research tries to shed light on this theme in Anderson's major selection of short stories Winesburg, Ohio(1919) as well as in other works like The Triumph of the Egg (1921) and his novel Poor White(1920) .

\section{Introduction}

Sherwood Anderson (1876 - 1941) is an author who strongly influenced American writing between World Wars I and II, particularly the themes and techniques of the short story. His writing had an impact on such notable writers as Ernest Hemingway and William Faulkner, both of whom owe the first publication of their books to his effort. ${ }^{1}$

Anderson's youth was deeply marked by his mother's early death in 1895. One of seven children of a day laborer; Anderson attended school intermittently as a youth in Clyde, Ohio, and worked as a newsboy, house painter, farmhand, and racetrack helper. After a year at Wittenberg Academy, a preparatory school in Springfield, Ohio, he worked as an 
advertising writer in Chicago until 1906, when he went back to Ohio and for the next six years sought-without success-to prosper as a businessman while writing fiction in his spare time.

Anderson went back to his advertising job in Chicago and remained there until he began to earn enough from his published work to quit. Encouraged by Dreiser, Floyd Dell, Carl Sandburg, and Ben Hechtleaders of the Chicago literary movement - he began to contribute experimental verse and short fiction to The Little Review, The Masses, the Seven Arts, and Poetry. Dell and Dreiser arranged the publication of his first two novels, Windy Macpherson's Son (1916) and Marching Men (1917), both written while he was still a manufacturer. Winesburg, Ohio (1919) was his first mature book and made his reputation as an author. Its interrelated short sketches and tales are told by a newspaper reporternarrator who is emotionally stunted in some ways like the people he describes. His novels include Many Marriages (1923), which stresses the need for sexual fulfillment; Dark Laughter (1925), which values the "primitive" over the civilized; and Beyond Desire (1932), a novel of Southern American textile mill labor struggle.

His best work is generally thought to be in his short stories, collected in Winesburg, Ohio , The Triumph of the Egg (1921), Horses and Men (1923), and Death in the Woods (1933). Also valued are the autobiographical sketches A Story Teller's Story (1924), Tar: A Midwest Childhood (1926), and the posthumous Memoirs (1942), a selection of his letters appeared in $1953 .^{2}$

Anderson's major work is Winesburg, Ohio (1919).It is also considered his great book of loneliness; it has an artistic unity not possessed by any of his other works, partly because of this central theme linking the stories, and partly through the character of George Willard. George grows into maturity by discovering his own loneliness and that of the people around him. Anderson's early stress in the book is on the isolation which his characters experienced in the small town mid - West America, but by the end it becomes clear that this society is itself breaking up. Everyone in Winesburg takes it for granted that an active young man must go away if he is to make anything of his life. In the last story ' 
departure ' George leaves home to find himself in exile, in the double loneliness of the big city.

George Willard is the town's newspaper reporter, and at first sight this would put him in touch with everything that happens. People even tell him their life stories and sufferings and this contact gives him a real chance to be a central, linking character. One of the simplest and most poignant tales in Winesburg, Ohio is ' Mother '. Elizabeth Willard has been a beautiful and dreaming woman in her youth, but now she has sunk into a drab middle age, weakened by illness, neglected by her husband, and out of touch with her son. The terrible futility of her life is presented by the savage battles she is forced to watch from her window, between the baker Abner Groff and a grey alley- cat which tries to slink in at the back of his store. Such things made her half -mad. One evening, she overhears her husband urging their son, George to ' wake up ' and embark on a business career. She is filled with rage and hatred for the man who she feels has stifled her own life and now threatens her son. Before her marriage she had wanted to be an actress, and she determines to kill her husband in the tragic manner of Lady Macbeth. But she finds that she does not have the strength for this role and in a conversation with her son George a few minutes later finds herself repeating helplessly the platitudes that had made her think of killing her husband. Her tragedy is not merely that she has been unable to live her own life, but that she cannot tell her son about her failure, so that he may avoid it.

Elizabeth Willard's loneliness is due primarily to her being unable to express her ideas: she does not have a language in which she can express her deepest feelings, or communicate with those she cares for most. The important point here is that Elizabeth has never been given the opportunity to find out her abilities. Her wide imagination is driven underground were it turns to be pitiful and self - destructive as in her plan to stab her husband with a pear of sewing scissors.

In 'Adventure' Anderson records another success in finding ways of evoking the isolation caused by the lack of communication. In this story, Alice Hindman has been deserted by her lover, but she goes on imagining that one day he will write to her. She takes a job in a dry - goods store, 
where she lives in a complete isolation waiting for the letter. Eventually she realizes that her lover will never send a letter, and one night, motivated by loneliness and sexual desire, she takes off her clothes and runs out into the rain, trying to speak to the world through her naked body. But she realizes, too, that even this language will not speak in her society which does not understand anything in her movement other than the shameful sexual desire of the body.

There are many characters like Alice in Anderson's fiction whose loneliness becomes unbearable by the ways in which a puritan society prevents self expression. One of the finest stories in the collection is 'The Untold Lie'. In this story Anderson examines the provincial American midWest puritan traditions ${ }^{3}$. The conflict is presented through the contrasting figures of two farmhands and in the way each of them is trying to resolve a problem. Ray Pearson is a tamed, middle aged husband with nagging wife and half-a-dozen of children. His friend Hal Winters is a young, free man, drunker and women chaser. As they are working in the farm one day, Hal asks his older friend for advice. He has got a girl into trouble and is trying to decide whether to marry her or remain free. Ray is strongly disturbed and, unable to answer, walks away. According to all Ray's moral breeding, Hal should marry the girl but the idea of sinful love made him restless and he broods rebelliously over the prison of his own marriage. When Ray gets home, his shrill wife nags him as usual. He goes out and runs over the fields to tell Hal to stay free. But by the time he has begun to remember the pleasant evenings with his children, he realizes that whatever advice he gives Hal will be a lie, and since he cannot resolve the conflict in his mind he is forced to remain silent.

In two other stories 'An Awakening' and 'Queer', this lack of communication produces physical violence. The central characters successively: Ed Handy and Elmer Cowley, as a result of their lack of words, use their fists. "Much of the violence described in American literature can be traced to this source" thinks the critic Brain Way ${ }^{4}$.

It is significant that the story in Winesburg, Ohio that bears the title ' loneliness ' is about a painter. Enoch Robinson goes to live in New York, where other artists admire his pictures and become his friends. But when 
they discuss his work, he finds that he has not succeeded in communicating what he feels. He wants to tell them:

The pictures you see don't consist of the things you see and say words about. There is something else, something you aren't intended to see .... How dull to talk about composition and such things! Why do you not look at the sky and then run away as I used to do when I was a boy back there. ${ }^{5}$

Although not about artists, there are several other tales in Winesburg, Ohio which explore similar situations. In 'Hands ', 'Paper Pills' and 'Respectability' we are shown sensitive natures, creative minds and fine impulses hidden in personalities which look like eccentric or grotesque in their societies. They are among Anderson's best stories but ' Paper Pills ' has particular distinction because of the poetic richness of the image he uses to describe the sweetness of what is hidden in Doctor Reefy, the central character in the story ${ }^{6}$ :

The story of Doctor Reefy and his courtship of the tall dark girl who became his wife and left her money to him is a very curious story. It is delicious, like the twisted little apples which grow in the orchards of Winesburg. In the fall one walks in the orchards and the ground is hard with the frost underfoot. The apples have been taken from the trees by the pickers. They have been put in barrels and shipped to the cities ... On the trees are only a few gnarled apples that the pickers have rejected. They look like the knuckles of Doctor Reefy's hands. One nibbles at them and they are delicious. Into a little round place at the side of the apple has been gathered all of its sweetness. One runs from tree to the few knows the sweetness of the twisted apples.

(pp. 181-82)

The most remarkable of Anderson's stories of loneliness is 'unlighted lamps ', which appeared in his second collection, The Triumph of the Egg (1921). It is longer and more complex in structure than the other stories discussed in this research. Doctor Cochran and his eighteen yearsold daughter Mary, both find it impossible to express their feelings to each 
other, or for anyone else. The Doctor's wife left him when the daughter was an infant believing him to be a cold, silent man incapable of love, whereas he was in fact fond of her.

When the story opens he has just told Mary that he may die of heart failure at any time. This threat reflects on their relationship and the meaning of their lives. Mary is confused by the thought of how little seemed to take care of her and more confused by her sexual maturing the deep longing for the love and the warm physical contact she has never known. The town she lives in is changing rapidly becoming an industrial centre with a notable immigrant population. She finds the Italian families who have moved in with the new factory more congenial than the older rural Anglo-Saxon community, which had always insults her because of the scandal of her mother's departure. Although she loves her father, she knows that when he dies she will be free to go to Chicago. Doctor Cochran reflects on the past: the failure of his marriage and his relationship with Mary. These parallel trains of thoughts point to "a technical mastery in Anderson's work: images, fragments of conversation and random memories are all fused into a complex poetic structure". ${ }^{7}$

It is the presence of a powerfully suggestive central image that does most for the story's success ${ }^{8}$. Anderson associates moments in the Doctor's life when his feelings struggle with transitory gleams of flickering life. One evening, as the Doctor sits in his darkened office, he imagines he hears a woman rustling in the doorway, and calls out. He is uncertain, in his strange mood, whether it is his daughter Mary or his long departure wife. At that moment a farmer comes to fetch him, and strikes a match to see whether he is there. Shocked by the Doctor's voice, the farmer lets the match fall on the floor, where it burns feebly, throwing a grotesque light upwards on his legs. Doctor Cochran is reminded of a stronger, more beautiful light, which flickered briefly into life many years earlier: His wife, who was trying to furnish their apartment, had been given a quaint old mirror at a farm they were visiting. As they drove back through the country, she told her husband that she was pregnant:

The mirror on his knees caught the rays of the departing sun and sent a great ball of golden light dancing across the fields 
and among the branches of trees. Now as he stood in the presence of the farmer and as the little light from the burning match on the floor recalled that other evening of dancing lights, he thought he understood the failure of his marriage and of his life. On that evening long ago, when Ellen had told him of the coming of the great adventure of their marriage, he had remained silent because he had thought no words he could utter could express what he felt. There had been a defense for him built up. 'I told myself she should have understood without words and I've all my life been telling myself the same thing about Mary. I've been a fool and a coward. I've always been silent because I've been afraid of expressing myself - like a blundering fool. I've been a proud man and a coward. Tonight I'll do it. If it kills me I'll talk to the girl'?

But this impulse and self realization is defeated as all the others have been. Late that night when Doctor Cochran returns exhausted from delivering a child, his heart stops at the very moment when he is trying to collect his confused thoughts to speak to his daughter Mary. The light from a forgotten cigarette in a bystander's hand dances up and down in the darkness over his dead body.

\section{III}

Anderson's feelings about the American mid-West are highly ambivalent. On the one hand it is home: it gives him a warm sense of people he knows and understands intimately, and, at a deeper level, it is, as we saw in the story of Enoch Robinson, the source of all his deepest insights as an artis. ${ }^{10}$ On the other hand, it is a place where life intolerably narrow and restricted and where the niceness is balanced by a strong cruelty. This expresses itself by gossip, vicious practical jokes and the persecution of those who do not belong to the herd. Anderson exposes these shortcomings in the short stories "Nobody Laughed" and "Morning Roll Call"(Both from The Sherwood Anderson's reader), and in certain episodes of the novel Poor White. Sensitive men and women like George Willard and Mary Cochran must leave if they can, otherwise they will be 
warped and imprisoned like Wash Williams, the central character of 'Respectability ', whose grotesque appearance cuts him off from other people completely as if he were an ugly monkey in a cage .

For Anderson, the mid-West is not only a background for his characters, not even a set of conditions which helps to shape their lives. ${ }^{11}$ Like other American novelists - Hawthorne, Faulkner, and Steinbeck -he has a developed historical sense. The parts of the short story 'Godliness' in The Sherwood Anderson's Reader which deal with Jesse Bentley and the novel poor white are outstandingly good examples of this sense.

In Jesse Bentley, the fanaticism of the American protestant tradition and nineteenth century economic individualism combine to produce a diseased restlessness of spirit:

Jesse Bentley was a fanatic. He was a man who born out of his time and place and for this he suffered and made others suffers. Never did he succeed in getting what he wanted out of life and he did not know what he wanted. ${ }^{12}$

At first, in the post-civil war years, Jesse sees himself as an Old Testament man of God owing flocks and lands like his biblical namesake: Jesus. He is convinced that in acquiring more lands he is fulfilling God's plan. But as the pressure of industrialism comes to Ohio he gradually looses this vision, and begins to dream of fortunes to be made by 'shrewd men who bought and sold':

Finally he realized that the atmosphere of old times and places that he had always cultivated in his own mind was strange and foreign to the thing that was growing up in the minds of others. The beginning of the most materialistic age in the history of the world, when wars would be fought without patriotism, when men would forget God and only pay attention to moral standards, when the will to power would replace the will to serve and beauty would be forgotten in the terrible headlong rush of mankind toward the acquiring of possessions, was telling its story to Jesse the man of God as it was to the men around him. (p.97) 
Anderson's treatment of the development of Jesse Bentley reflects very strongly the dilemma of the American who sees his country emerging from Puritanism. He feels that Puritanism is hateful, cruel, bigoted and narrowing, and that an escape from it is spiritually necessary. Nevertheless, he finds that the American road away from Puritanism does not lead to liberation and a better life, but to materialism, impoverishment of spirit and a loss of human dignity. Instead of being imbued with the language of the Bible and the exalted imaginations aroused in him Jesse becomes obsessed merely with the vulgar commercialism of the provincial newspapers and business magazines which begin to spread with the coming of industry. ${ }^{13}$

Anderson explores this phase of historical development in America in a much larger scale in his novel Poor White (1920). Hugh McVrery, the central character grows up in a squalid little Mississippi town; his father is a drunken loafer. When the railroad reaches Hugh's home-town, Bidwell, he gets a job at the station, and Sara Sheppard, the station master's wife, takes him in hand. She is a New England woman the puritan tradition personified - and she makes Hugh clean, industrious and ambitious. His imaginative life is eliminated along with his idling, and he moves away from the stagnating river life to the Ohio town of Bidwell. At first there appear to be some compensatory gain: it is in his new way of life, his struggle to acquire a new identity - a puritan identity - that he finds the drive which makes him an inventor and a creative mind. His invention of a machine for planting cabbages gives Bidwell its factory and initiates a rapid industrial growth. But Hugh has to pay for this new creativity by losing all his spontaneity of response. His imaginative life has been closely linked with the life of the senses- the luxurious and daydreaming of the Mississippi shore - and when he loses this he is cut off from other people and his inner life impoverished. He is socially isolated, he has no friends, and his capacity for love or any kind of sexual relationship has been weakened. In the long run, the failure of his marriage with Clara Butterworth can be put down to this deprivation.

The second stand in his destruction is the industrialization he himself has done so much to bring about. The greed of his father - in - law Tom Butterworth (a debased version of Jesse Bentley) finally destroys the very 
creativity in Hugh by the puritan tradition. Towards the end of the novel the reader finds that Hugh's latest invention -a hay loader- has been forestalled by the work of another inventor in Lowa. Tom Butterworth, finding that the other man has no financial backing, sets Hugh to modify his design so that they can get round the patent. Hugh finds that he is unable to work in the climate created by this swindle. His imagination partially reawakens but not in a way that helps him to re- order his life: he cannot create a relationship with his wife, but can only come to her unwillingly like an animal in the dark for sexual relief. At the end he seems to regress into a kind of mindless dreaminess, playing for hours with a few colored stones.

It is clear from the story of Hugh McVery that Anderson takes an extremely pessimistic view of what American civilization, during the phase of industrialization, has done to many individual Americans ${ }^{14}$.It is also true that industrialization had developed the farming communities bringing them to maturity out of their narrowness and provincial isolation but instead of a slow flowering into a life of amenity which the old farming life had lacked, industry struck the mid - West a paralyzing blow which destroyed all human morals and values:

A sense of quite growth awoke in sleeping minds. It was the time for art and beauty to awake in the land. Instead, the giant, industry, awoke. Boys , who in the schools had read of Lincoln walking for miles through the forest to borrow his first book, and of Garfield , the towpath boy who became president, began to read in the newspapers and magazines of men who by developing their faculty of getting and keeping money had become suddenly and overwhelmingly rich. Hired writers call these men great ${ }^{15}$

Such an explicit analysis, which is one of the main reasons of the success of the novel Poor White according to the critic Malcolm Cowley, depends on Anderson's power to present his vision through the genius creation of scene and character. ${ }^{16}$ 
Conclusion:

The distinctive quality of Sherwood Anderson's writings reflects a writer of a high influence on his young contemporaries. He grew up in the last years of the nineteenth century and his first major work Winesburg, Ohio (1919) was a seminal influence on the American new literature of the nineteen twenties. In these years both American society and American literature were witnessing the most fundamental changes that had occurred in American history since the period of independence. Anderson lived through the industrialization of the American mid - West, one of the most dramatic phases in the shift from a predominantly rural to mainly urban civilization. He saw Puritanism degenerate into the business ethics. As an advertising copy - writer and journalist, he was forced to participate in the first debasement of American popular culture by the mass media. And as an artist he helped - with others-to bring about the rejection of the genteel tradition in American literature. He experienced that painful emergence from a provincial consciousness and expressed it in his fiction as a sense of loneliness and isolation in many of his characters.

\section{Notes :}

${ }^{1 .}$ Encyclopedia Britannica 2010, Deluxe Edition C D .Sherwood Anderson.

2. James Schevill. Sherwood Anderson: His Life and Work (Denver: Alfred A. 1951) p. 16.

3. Brian Way "Sherwood Anderson "in The American Novel and The nineteen Twenties (London: Edward Arnold, 1982) p109.

4. Ibid. p.111.

5. Sherwood Anderson. Winesburg Ohio (New York:Perma Books, 1980, \{ first published 1919\}) p.116. All subsequent references to the stories in this collection are taken from this edition and will be referred to by page number only in the text. 
6. The critic Michael Spindler had noticed this distinction in his book American Literature and Social Change (London: MacMillan Press Ltd.1996.) see p.162-63.

${ }^{7}$ Brian Way, p.114.

${ }^{8 .}$ Ibid, p.116.

9. Sherwood Anderson. The Triumph of the Egg (New York: Perma Books, 1980, \{first published 1922\} ) pp.33-34.

10. Maxwell Geismar. The last of the Provincials (Boston: Twayne 1999) p33.

11. Ibid, p38.

12. Ray Lewis (Ed.). The Sherwood Anderson's Reader (New York: Appleton 1960) p 92.

13. Maxwell Geismar, p.39.

14. Irving Howe. Sherwood Anderson (New York: Collier Books 1951) p 39.

15. Sherwood Anderson. Poor White (New York: Perma books 1980 \{first published 1920\}) p 46 .

${ }^{16 .}$ Malcolm Cowley. Writers at Work (London: Penguin Books1962) p.72. 


\section{References:}

Anderson, Sherwood. Winesburg, Ohio . New York: Perma Books, 1980. The Triumph of the Egg. New York: Perma Books, 1980.

Poor White .New York: Perma Books 1980.

Cowley, Malcolm. Writers at Work. London: Penguin Books, 1962.

Encyclopedia Britannica 2010, Deluxe Edition C D .

Geismar, Maxwell. The Last of the Provincials. Boston: Twayne 1999.

Howe, Irving. Sherwood Anderson. New York: Collier Books1951.

Lewis, Ray (ed .) The Sherwood Anderson's Reader . New York:

Appleton 1960.

Schevill, James. Sherwood Anderson: His Life and Work . Denver: Alfred A. 1951

Spindler, Michael. American Literature and Social Change London: MacMillan Press Ltd.1996.

Way, Braian. "Sherwood Anderson "in The American Novel and The Nineteen Twenties. London: Edward Arnold, 1982. 


\section{موضوعة الوحدة والانعزال في قصص شيروود أندرسون

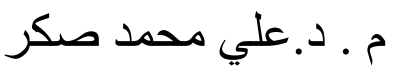 \\ كلية المأمون الجامعة \\ قسم اللغة الانكليزية}

\section{خلاصة البحث}

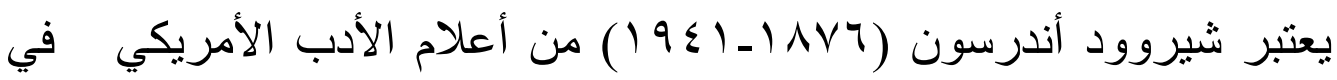

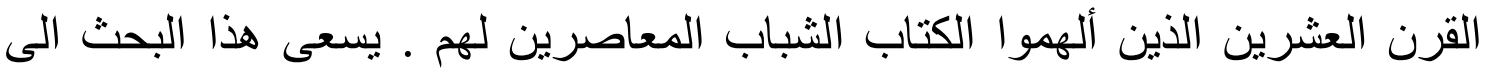
التعريف بالكاتب ومنجزه في الأدب القصصي الأمريكي في إحدى أهم مر احل هذا

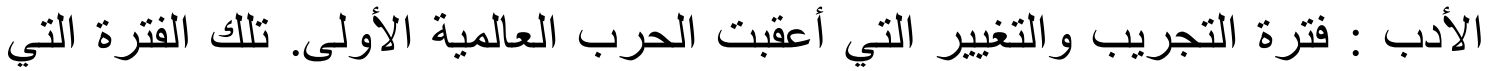

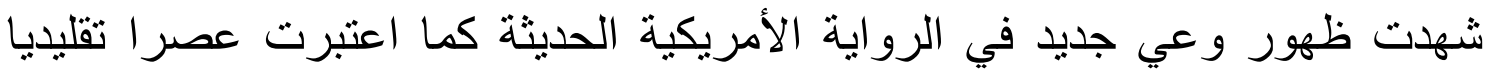

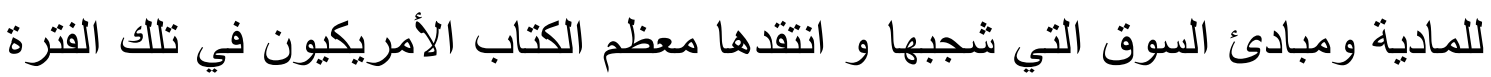

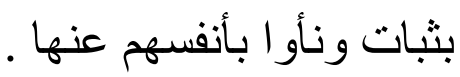

و تبدو موضوعة الوحدة و الانعز ال جلية في كتابات أندرسون و انعكاسا طبيعيا

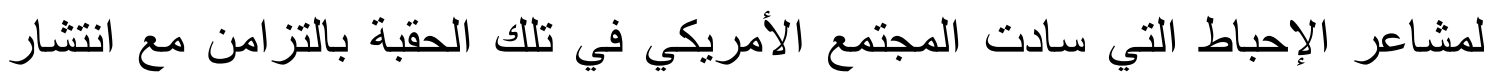

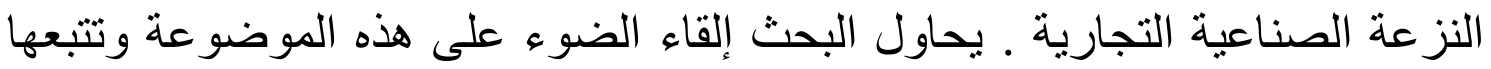

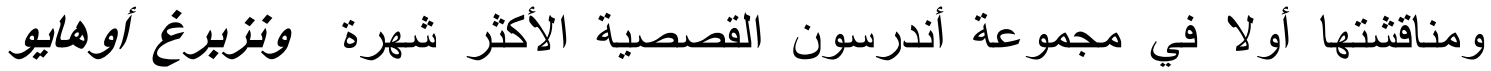

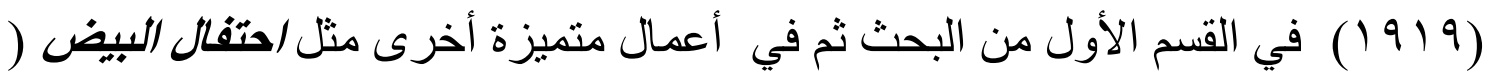

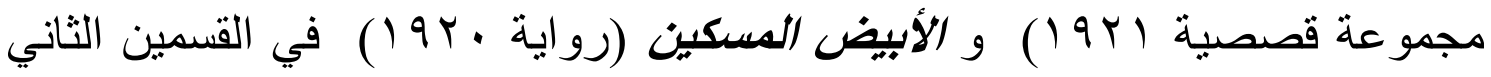
و الثالث . 